\title{
EL PAPEL DEL CLERO REGULAR EN LA ORDENACIÓN DEL PAISAJE. EL CASO DEL MONASTERIO DE SAN JULIÁN DE SAMOS*
}

\author{
POR \\ ESTEFANÍA LÓPEZ SALAS ${ }^{1}$ \\ Universidade da Coruña
}

\section{RESUMEN}

El presente estudio busca comprender cuál fue el grado de implicación de los monjes de San Julián de Samos (Lugo) en la forma de ordenar, transformar y desarrollar el amplio territorio de su coto jurisdiccional. Para ello, acudimos a fuentes históricas hasta el momento inéditas, con la finalidad de descubrir las reglas, los intereses y los instrumentos que, con un sentido planificador, se utilizaron para definir la estructura original del paisaje humanizado que hoy habitamos.

PALABRAS CLAVE: Clero regular; ordenación; paisaje; escrituras de foro o arrendamiento; coto jurisdiccional.

\section{THE ROLE OF THE REGULAR CLERGY IN THE PLANNING OF THE LANDSCAPE. THE CASE OF SAN JULIÁN DE SAMOS}

\begin{abstract}
The present study seeks to understand what was the level of implication that the monks of San Julián de Samos had in the way of planning, changing and developing the large territory of their jurisdictional reserve. To achieve that goal, we resort to some historical, unpublished sources to reveal the rules, the interests and the instruments which, with a clear planning sense, were used to define the former structure of the inhabited landscape where we live nowadays.
\end{abstract}

KEY WORDS: Regular clergy; planning; landscape; tenancy agreements; jurisdictional reserve.

Cómo CITAR ESTE ARTículo / CitATION: López Salas, E. (2017). «El papel del clero regular en la ordenación del paisaje. El caso del Monasterio de San Julián de Samos». Hispania Sacra 69, 139: 19-29. doi: 10.3989/hs.2017.002

\author{
Recibido/Received 13-05-2014 \\ Aceptado/Accepted 16-10-2014
}

\section{INTRODUCCIÓN}

Además de los edificios que configuran el monasterio de San Julián de Samos, entre el siglo VIII y la tercera década del XIX, su comunidad poseía un conjunto de propiedades agrícolas que les permitían mantenerse y sobre las cuales ejercían un dominio. La mayoría de esos bienes eran terrenos que rodeaban el monasterio, definiendo un área circular con unas dimensiones primitivas de una milla

"Este trabajo ha sido parcialmente financiado por la Universidade da Coruña (Ref.: Ayuda de apoyo a la etapa predoctoral UDC 2011) y por la Xunta de Galicia (Ref.: Ayuda de apoyo a la etapa predoctoral del Plan Gallego de Investigación, Innovación y Crecimiento 2011-2015 - Plan IC2), cofinanciado por el Fondo Social Europeo (FSE-FEDER).

1 estefania.Isalas@udc.es/ORCID iD: http://orcid.org/0000-0002-2889-6465 y media. Ese territorio es lo que se llamaba coto jurisdiccional. En ese ámbito delimitado, los monjes de Samos eran, por concesión regia, los señores a nivel espiritual, material y judicial. ${ }^{2}$ Su autoridad se extendía tanto sobre los bienes que conformaban el coto, como sobre las personas que en él habitaban.

En el periodo temporal indicado, las características físicas del medio elegido como lugar de asentamiento por los fundadores del monasterio y las del entorno territorial que lo rodeaba, condicionaban las actividades de los monjes y

2 Señala Pallares Méndez que la concesión de un coto llevaba aparejada una serie de exenciones y privilegios: «En primer lugar, la delimitación de un espacio de amplitud variable. En segundo lugar, la inmunidad del espacio acotado. Y, por último, el derecho a ejercer, por parte de los señores, funciones propias del poder público y acaparar las rentas derivadas de este ejercicio». Pallares Méndez 1978. 
las de sus vasallos, pero, a la vez, estos fueron modificando poco a poco ese territorio con el objetivo de mejorar sus condiciones en su propio beneficio. El medio y los individuos interactuaron en el tiempo, dando como resultado un territorio humanizado o paisaje histórico, en el que el emplazamiento original se vivificó como resultado de su actividad. ${ }^{3}$

En el presente artículo nos proponemos comprender cuál fue el papel jugado por los monjes, en su calidad de gobernantes, ${ }^{4}$ en la forma de habitar y ordenar el territorio de su coto jurisdiccional. Para alcanzar ese objetivo nos preguntamos si, en su posición de únicas autoridades, los monjes establecieron reglas que les permitiesen controlar una adecuada ordenación del paisaje, si existieron intereses que prevalecieron sobre otros en la forma de habitar el medio $y$, sobre todo, si utilizaron algún tipo de instrumento para garantizar que la transformación de éste fuera ejecutada de acuerdo con los deseos de la comunidad (Figura 1).

La enorme extensión del coto jurisdiccional y el largo periodo de dominio monacal sobre el mismo, de casi once siglos, provoca que en este estudio sólo abordemos el alcance de los objetivos anteriormente planteados en unas áreas concretas del coto y en un periodo temporal determinado. En ambos casos, la elección está directamente vinculada a las fuentes históricas empleadas en la realización de este trabajo. Se trata de un conjunto de escrituras de foro generadas por los propios monjes, desde principios del siglo $\mathrm{XVI}$, hasta los años treinta del periodo decimonónico. ${ }^{5}$ Tanto su abundancia, como el tipo de información que contienen, las convierten en fuentes históricas de gran relevancia para conocer la formación y evolución de ciertas áreas del territorio jurisdiccional y el papel jugado por los monjes en su ordenación. A través de su estudio y análisis, así como del conocimiento in situ de los bienes cuyo foro aquellas contienen, en este artículo buscamos identificar los posibles destellos de un plan de ordenación del territorio jurisdiccional, en el sentido contemporáneo del término, así como la existencia o no de un planificador detrás de ese proceso.

Si atendemos a los restos arqueológicos que han llegado hasta nuestros días, los asentamientos en el territorio circundante al lugar de implantación del monasterio de Samos datan de tiempos muy antiguos y su lectura muestra que el proceso de poblamiento de ese ámbito comenzó en la prehistoria. Este es un fenómeno propio de noroeste peninsular, del cual tenemos constancia por la permanencia de túmulos funerarios y castros. Sobre los primeros pasos dados hacia la población de lo que, avanzando en el tiempo, sería el coto jurisdiccional de Samos, véase López Quiroga y Rodríguez Lovelle 1999-2000.

4 Dentro de los límites del coto, la comunidad de Samos ejercía sus derechos jurisdiccionales, hecho que marcaba una diferencia de base jurídica importante con otras propiedades monásticas. Los reyes le concedieron facultades que le correspondían al poder público, es decir, funciones de carácter fiscal y judicial. Asimismo, el coto de Samos gozaba de independencia respecto de la autoridad episcopal. Por ello, con el tiempo el monasterio fue denominado «nullius dioeceses» y estaba directamente sujeto a la Santa Sede y no al obispo de Lugo. Como señala Arias Cuenllas, Samos era «una especie de diócesis dentro de otra diócesis». Este privilegio se mantuvo hasta 1873, fecha de la bula del Papa Pío IX en la que se suprimían todas las jurisdicciones eclesiásticas que gozaban de tal exención. Arias Cuenllas 1992: 406.

5 Todas las escrituras de foro aquí analizadas se conservan en el Archivo Histórico Nacional de España, en el «Fondo de Instituciones Eclesiásticas», dentro de la sección de "Clero secular-regular», categorías de «Legajos» y «Libros». No hemos incluido en este estudio los foros y otros documentos, de fecha anterior, que también se conservan en el Archivo Histórico Nacional, dentro del mismo fondo documental, pero en la categoría de «Carpetas». De su estudio se han ocupado los trabajos de: Rodríguez Cancio 1978; Ríos Rodríguez 1991 y 1993.
FIGURA 1

\section{El territorio circundante al monasterio de San Julián de Samos en la segunda mitad del siglo $\mathrm{xx}$}

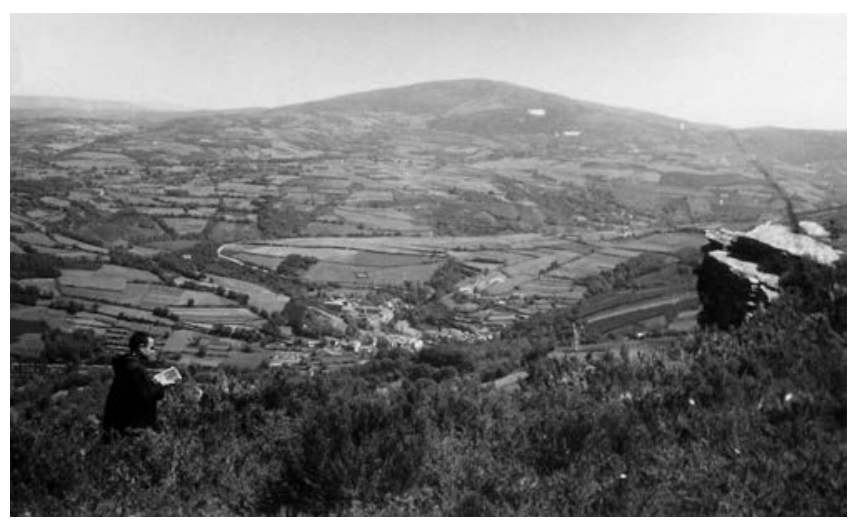

Fuente: Fondo fotográfico del Monasterio de Samos

\section{EL COTO JURISDICCIONAL: ORIGEN Y ÁMBITO}

Abordar el estudio de un paisaje histórico implica, en primer lugar, conocer los límites que lo definieron en el pasado. Para ello es necesario acudir a la única fuente histórica directa que se conserva del periodo que abarca desde el siglo VIII al XII, el Ilamado Tumbo de Samos. ${ }^{6}$ Se trata de un códice en pergamino formado por más de doscientos documentos de época medieval a través de los cuales podemos realizar un tímido acercamiento al conocimiento de los límites que poseía el coto del monasterio, de los lugares, tierras, villas e iglesias, que se encontraban dentro de su ámbito de influencia, así como de algunas de sus ampliaciones acometidas por mandato real.

En el siglo VIII, el rey Fruela I estableció el coto de la abadía en una milla y media, además de ceder a los monjes un conjunto de villas fuera de los límites de aquel. ${ }^{7}$ Los reyes que se fueron sucediendo tras él, confirmaban siempre los privilegios y donaciones que habían hecho sus antecesores a través de la redacción de nuevas escrituras. ${ }^{8}$ En estos documentos reales también ha quedado constancia escrita de que, por orden del monarca reinante, los monjes de Samos eran los únicos señores con potestad sobre esas propiedades y sobre las personas que en ellas vivían, las cuales por habitar en esos territorios se convertían en vasallos del monasterio, al que tenían que pagar los tributos correspondientes y prestarles su servicio siempre que fuera necesario. ${ }^{9}$

La transcripción del documento manuscrito original fue realizada por Lucas Álvarez (1986). Del estudio de la formación y evolución del coto jurisdiccional del monasterio destacan los trabajos de Arias Cuenllas 1981, 1983 y 1992: 36-151, así como López Alsina 1993.

Señala Arias Cuenllas que no se conservan ni el original ni una copia del diploma que Fruela I redactó en favor del abad de Samos en el siglo VIII, pero los instrumentos elaborados por los reyes que le sucedieron indicaban que en aquel se establecía el coto de la abadía en una milla y media. Arias Cuenllas 1981: 286 y 1992: 37.

Así lo señalaban los diplomas del año 811 del rey Alfonso II, el del año 857 del rey Ordoño I, el expedido por el rey Ordoño II en 922 y el de Ordoño III de 951, entre otros. Arias Cuenllas 1981: 293-294, 301302, 312-313, 318-319, 335-336, 339-340; Lucas Álvarez 1986: 61-64, 123-125, 128-130; Arias Cuenllas 1992: 36-151; López Alsina 1993: 180. Arias Arias 1950; Arias Cuenllas 1981: 316, 319, 321; Arias Cuenllas 1992: 71, 74. Algo similar ocurrió en otros dominios monásticos gallegos que también fueron dotados de jurisdicciones privilegiadas. Es el caso, entre otros, de San Vicenzo de Pombeiro, del que se 
En algunas ocasiones los términos del coto eran invadidos por personas ajenas que intentaban apropiarse de ellos. Así ocurrió en el año 933, lo que obligó a los monjes a pedir ayuda al monarca Ramiro II, que encomendó a dos delegados, Teodoro Soffini y el presbítero Trevulcus, acudir a Samos y medir la milla y media, fijando los límites del coto por el norte, sur, este y oeste mediante mojones. ${ }^{10}$ En esta orden de amojonamiento se puso especial cuidado en la definición correcta de los límites por el oeste pues, según señala la escritura, los habitantes de las villas de Castrocán y Pascais entraban dentro de los términos del coto, para usurpar parte del villar conocido como Omerii. ${ }^{1}$

Algo similar volvió a repetirse en el año 993, cuando la comunidad elevó una queja a Vermudo II, informando de que varias personas habían movido las marcas que delimitaban la jurisdicción de Samos. La respuesta real consistió en enviar a un nuevo delegado, Piniolus Tructiniz, para que localizase los límites verdaderos, "lo midieron con las cuerdas y encontraron las «arcas firmissimas» o mojones que lo delimitaban: uno sobre Montán, otro sobre Zoo, otro al pie de Calvor, otro sobre Venta de Córneas, etc.». ${ }^{12}$

Los datos aportados por estas escrituras nos permiten hoy esbozar sobre un plano los límites aproximados del coto primitivo, para una mejor comprensión de cómo pudo haber sido (Figura 2). ${ }^{13}$ Pero, al mismo tiempo, la representación espacial de los mojones citados, pone de manifiesto que, entre el año 933 y el 993, se produjo un claro creci-

sabe que «entre los derechos concedidos estaban el de nombramiento de juez y notario para los cotos». Lucas Álvarez y Lucas Domínguez 1996. Asimismo, el monasterio de San Esteban de Ribas de Sil contaba desde la Edad Media con un coto jurisdiccional que fue ratificado por sucesivas confirmaciones reales. En él el abad ejercía un señorío temporal, lo que implicaba una suma de deberes y obligaciones por parte de la comunidad: "El señor tomaba a su cargo la protección de sus vasallos, los defendía del servicio a otros señores, como no fuese el rey, garantizaba la seguridad de sus personas y la posesión pacífica de sus bienes, administraba justicia, socorría necesidades y repartía mercedes (...) A su vez, el vasallo debía al señor, además del respecto y la obediencia, ciertos tributos, servicios y prestaciones». Duro Peña 1977: 222.

10 Arias Cuenllas 1981: 318-319; Lucas Álvarez 1986: 142-143; Arias Cuenllas 1992: 71; López Alsina 1993: 180-181. La frase completa en la que el Ramiro II ordena la restitución de los límites verdaderos del coto samonense es: "Etenim venientes a supradicto principe missi, nominubus Theodemirus Soffini et Trevulcus presbiter, posuerunt determinationem, mecientes miliarium et semis per circuitum monasterii quatuor partibus, sicut narrant testamenta regum pro avorum regis huius vel parentum, quorum nomina hec sunt: Adefonsus cognomento catholicus, et successor illius in regno Ranemirus; post quem Hordonius,(...)» Lucas Álvarez 1986: 143.

11 López Alsina 1993: 180-181. El extracto en el que el rey Ramiro II señala la invasión de los términos de Samos por los vecinos de Castrocán y Pascáis es: "Ergo ipsi predicti missi atque provisores, determinantes, posuerunt archas, fregeruntque superbiam hominum habitantium in villis, qui nuncupantur Uncani ac Paschasi, qui intraban infra terminos iam dicti monasterii Samanos sancti luliani, infringentes testamenta regum; usurpaverunt villare qui dicitur Omerii porcionem, ob quod iam Offilus abba vindicans, (...)» Lucas Álvarez 1986 143. López Alsina identificó Uncani como Castrocán y Paschasi como Pascais. Falta por identificar Omerii.

12 Arias Cuenllas 1992: 93. Con esa explicación, Arias Cuenllas nos está traduciendo parte del documento del n 40 del Tumbo de Samos transcrito en Lucas Álvarez 1986: 133-135. La frase completa en la que quedan descritas las marcas es: "una que vocitant super Montan; alia que dicunt Samanega super Zalon; et inde alia Petra Ficta sub Calvor; et deinde per Sarambello; et inde ad aliam arcam ubi dicunt Cornias; et inde per castro Saliceto.» Faltan por identificar Sarambello y cas tro Saliceto. A este documento también hace referencia López Alsina 1993: 181-182.

13 Las primeras representaciones gráficas del coto de Samos en la bibliografía contemporánea las encontramos en: Rodríguez Cancio 1978; Arias Cuenllas 1981: 332; Arias Cuenllas 1992: 84. miento del perímetro del territorio jurisdiccional de Samos. Veamos el porqué de esta afirmación.

Si tomamos como centro del coto el lugar de Samos, los límites del primitivo territorio jurisdiccional del monasterio los obtenemos dibujando un círculo de radio una milla y media. Una milla, medida itineraria utilizada por los romanos, equivalía a $1.478,5 \mathrm{~m} .{ }^{14}$ Por tanto, una milla y media eran $2.217,75 \mathrm{~m}$ de radio, lo que daba como resultado un coto de una superficie de aproximadamente de $15 \mathrm{~km}^{2} .^{15}$ Los límites de este primer coto parecen coincidir con los datos recogidos por la escritura del año 933, en la que se señalaba que, por el oeste, tanto Pascais como Castrocán estaban fuera del dominio samonense. ${ }^{16}$

FIGURA 2

El área del coto primitivo de una milla y media, frente al ámbito jurisdiccional samonense de acuerdo con los límites descritos en el documento real expedido por el rey Vermudo II en el año 993

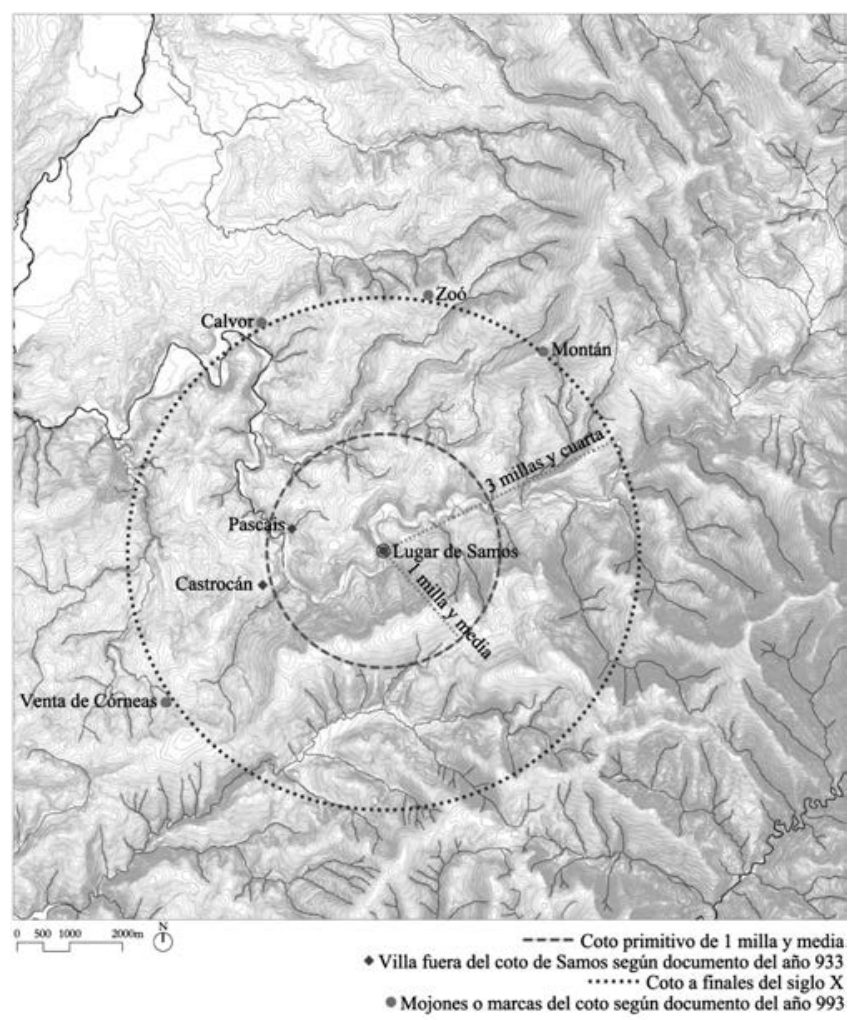

Fuente: Elaboración propia sobre la hoja no 124 de la base cartográfica del Sistema de Información Territorial de Galicia (en adelante, SITGA)

14 Diccionario de la Lengua Española [en línea]. Vigésima segunda edición. Madrid: Real Academia Española, 2001. Disponible en web: <http://buscon.rae.es/drael/> Así lo afirma también López Alsina 1993: 160.

15 Señala López Alsina que entre los siglos VIII y XI, sólo dos iglesias, dentro del reino asturleonés, contaban con un circuito jurisdiccional medido en millas en torno a ellas. Esas dos iglesias eran la de San Julián de Samos y la de Santiago de Compostela. Frente al coto de una milla y media que se concedió a San Julián de Samos, Santiago de Compostela fue dotada de un primer giro de tres millas, por el rey Alfonso II en el año 834, que sería ampliado hasta las seis millas en el año 858. Sobre el giro de la ciudad de Santiago de Compostela, su formación, evolución y significado se pueden consultar los trabajos de López Alsina 1995 y 2013.

16 Aunque las escrituras reales hablan de un coto de forma circular o girum ecclesiae, el perímetro real fue adaptado a las condiciones topográficas del terreno, resultando no ser un círculo exacto. 
Sin embargo, los mojones relacionados en la escritura del año 993, Montán, Zoó, Calvor y Venta de Córneas -cuyos topónimos son identificables en la cartografía actual-, están ubicados a una distancia mucho mayor del lugar de Samos, centro del coto. Sus posiciones, entendidas como marcas límites de un perímetro, definen un territorio jurisdiccional de igual forma circular que el primitivo, pero de radio mucho mayor. Frente a la aproximadamente milla y media que existe entre Castrocán y Samos, la distancia aumenta hasta cerca de las tres millas y un cuarto entre Montán, Zoó, Calvor, Venta de Córneas y el lugar de Samos. De esta forma, en el año 993 el coto de Samos había crecido hasta abarcar una superficie circular de aproximadamente $74 \mathrm{~km}^{2}$.

A lo largo del siglo XII, estas demarcaciones todavía se ampliaron más, principalmente como consecuencia de dos mandatos regios..$^{17}$ En el año 1146, el rey Alfonso VII redactó un diploma por el cual aumentaba los límites del coto del monasterio por el suroeste, incluyendo entre ellos, los territorios de Toldaos, Santa Cristina, el castro de Sirgueiros y hasta el otro lado de la montaña de O Couso. ${ }^{18}$ En 1161, Fernando II, lo incrementa por el oeste anexionando la iglesia de Sancti Martini y su parroquia, hoy San Martín de Loureiro, así como las villas de Ville Nove y Avoin, las actuales Vilanova y Abuín ${ }^{19}$ (Figura 3).

Estos primeros datos recogidos por las escrituras del Tumbo nos permiten comprender que, entre los siglos VIII y XII, ya existía toda una estructura territorial bien ordenada, un paisaje que empezaba a humanizarse y cuyo devenir estaba en manos del monasterio, dueño y señor de todas esas propiedades y de las personas que vivían y trabajaban en ellas, auténticos vasallos de la comunidad. De hecho, en la bula del papa Alejandro III, del año 1175, se relacionaban alrededor de un centenar de iglesias que, con su correspondiente territorio parroquial, estaban bajo la protección

17 Además de las propiedades que formaban el coto, el monasterio poseía otros bienes fuera de los límites de su jurisdicción. Del estudio de la formación del patrimonio material del monasterio de Samos durante la época medieval y los mecanismos utilizados se han ocupado los siguientes autores: Arias Arias 1950: 1-179; Rodríguez Cancio 1978; Arias Cuenllas 1981: 269-350; Arias Cuenllas 1983: 7-81; Arias Cuenllas 1992: 36-151; Vázquez González 1991; Andrade Cernadas 1997; Rodríguez González 2008.

18 Arias Cuenllas 1992: 134. Se corresponde con el documento no 57 del Tumbo de Samos transcrito en Lucas Álvarez 1986: 168170. La frase completa en la que queda descrita la ampliación es: "Amplifico, inquam, illud per illam lagenam que est inter Toldanos et Sanctam Cristinam, et ex inde per illam cerdariam de Lobos, et inde per illo castro de Sirgarios, et inde per stratam usque ad Campello, et ex alia parte per montem Mocosum.» Faltan por identificar Lobos y Campello. Aunque, tanto Lucas Álvarez, como Arias Cuenllas, hablan de una ampliación por el sureste, la localización de estos lugares en la cartografía actual nos permite comprobar que todos ellos se encuentran realmente al suroeste. No obstante, la orientación hacia el sureste que ambos autores señalan, tras la lectura del documento original, sí sería la correcta si en aquel momento la posición de aquéllos se puso en relación con la cabecera de la antigua iglesia conventual.

19 Arias Cuenllas 1992: 139. Se corresponde con el documento del no 60 del Tumbo de Samos transcrito en Lucas Álvarez 1986: 174175. Al igual que en el caso anterior, tanto Lucas Álvarez como Arias Cuenllas hacen referencia a una ampliación de terrenos por el suroeste del coto. De nuevo, esta orientación sería la correcta si, en el momento de la redacción de la escritura, la situación de estas tierras se puso en relación con la cabecera de la antigua iglesia románica, que miraba hacia el noreste, casi alienada con la actual disposición de los muros del ala noroeste del claustro de las Nereidas, tal y como demuestran los restos que de ella conservamos. Sin embargo, la localización de estos lugares en la cartografía actual, como podemos observar en los planos que acompañan este trabajo, pone de manifiesto que su orientación real es al oeste del coto jurisdiccional. de Samos, ${ }^{20} \sin$ tener en cuenta aquí las villas y heredades, que agrandaban aún más su patrimonio (Figura 4). Pero, en estos primeros documentos todavía no encontramos referencias claras al papel jugado por los monjes en la planificación del territorio, aunque evidentemente su posición de autoridades los convertía en los primeros responsables de su ordenación.

\section{FIGURA 3}

Expansiones del coto jurisdiccional realizadas en 1146 y 1161 como consecuencia de las órdenes recogidas en los diplomas expedidos por los reyes Alfonso VII y Fernando II, respectivamente

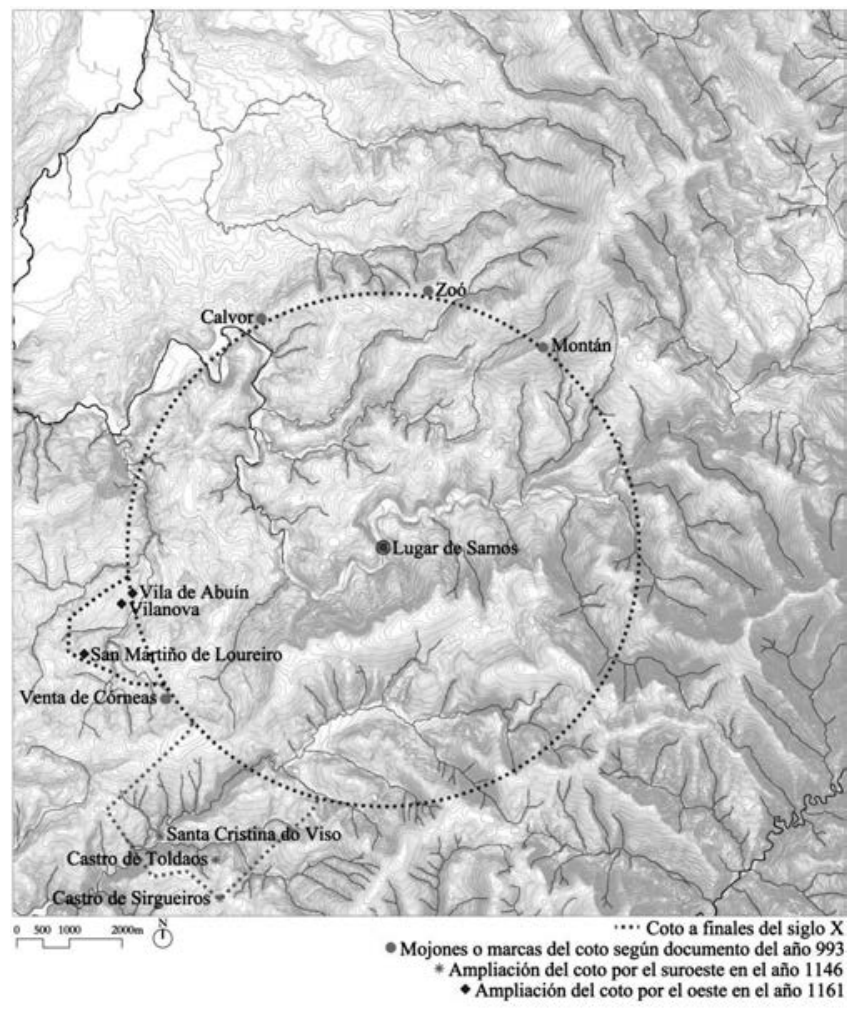

Fuente: Elaboración propia sobre la hoja no 124 de la base cartográfica del SITGA

LAS REGLAS DE ORDENACIÓN DEL PAISAJE MONÁSTICO EN LOS DOCUMENTOS HISTÓRICOS

La enorme extensión del coto jurisdiccional hacía inviable que los monjes asumiesen su cuidado de forma directa. Por esa razón, al igual que otras clases sociales gallegas, aunque la comunidad tenía el dominio directo de las tierras no ejercía su explotación directa, sino que se veía obligada a la cesión de buena parte de sus bienes a segundas personas.

Dentro de los límites del coto jurisdiccional de Samos podemos distinguir dos tipos básicos de cesión del terrazgo, el llamado foro y el arriendo, que podían ser a largo plazo e incluso a veces perpetuos. De las dos fórmulas, de estructura muy similar, la más utilizada en el caso que nos ocupa, y en Galicia en general, fue el foro. La primera referencia a

\footnotetext{
20 Arias Cuenllas 1992: 143; Lucas Álvarez 1986: 153-157.
} 
la realización de un foro por parte del monasterio data de $1192,{ }^{21}$ por tanto, fue un instrumento empleado desde la época medieval en adelante. En cuanto al arriendo, la primera alusión a este tipo de contratos la encontramos en un pacto otorgado en favor del abad del monasterio de Samos en 1080.22 Por tanto, su uso, aunque menor, también se inició en el periodo medieval, si bien entre la documentación de la edad moderna utilizada en este trabajo, los arriendos que se conservan no fueron expedidos hasta el siglo XVIII.

FIGURA 4

Posesiones del monasterio de Samos en su entorno territorial cercano de acuerdo con diversos documentos contenidos en el Tumbo de Samos

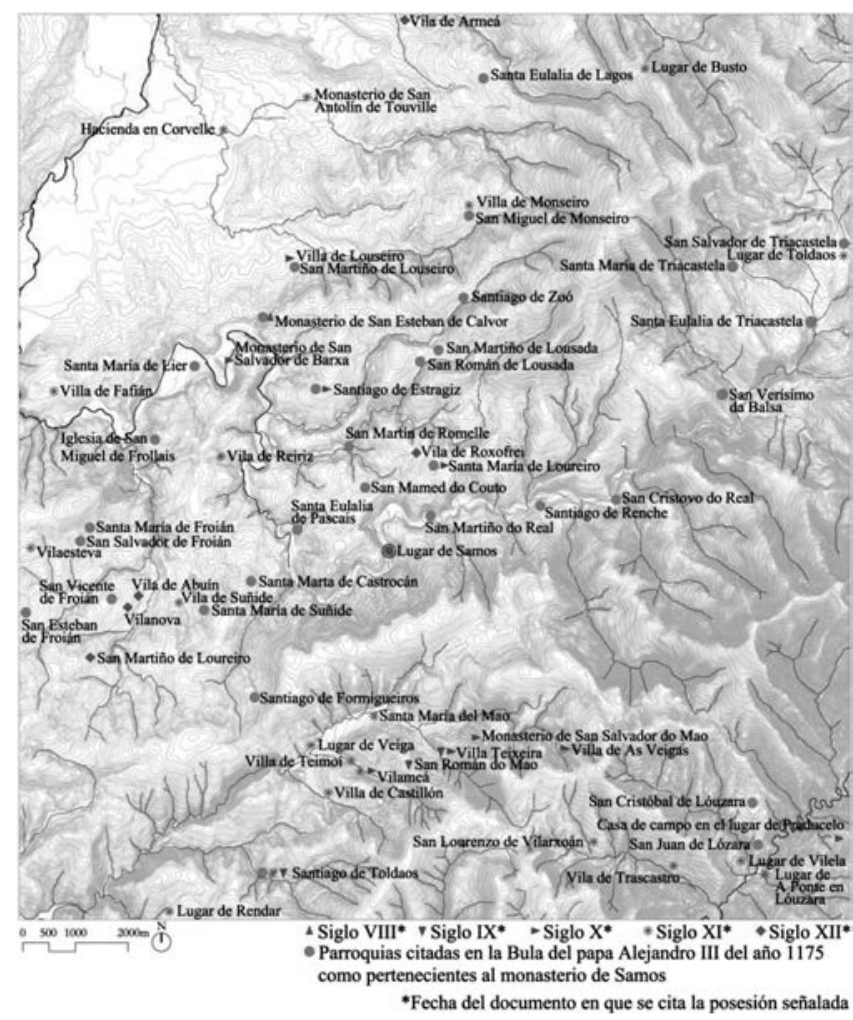

Fuente: Elaboración propia sobre la hoja no 124 de la base cartográfica del SITGA

Las escrituras de foro eran contratos a través de los cuales el monasterio cedía una o varias de sus propiedades a una persona, a cambio de que esta cumpliese con todas las condiciones establecidas en la escritura, entre las que figuraba siempre el pago de una renta. ${ }^{23}$ Como contrato, el foro tenía el carácter de documento jurídico, por el cual el monasterio y la persona receptora de las propiedades adquirían derechos y obligaciones recíprocas. Por ello, en cada foro se especificaban de forma precisa todo un con-

\footnotetext{
21 Arias Cuenllas 1992: 149. Se trata de la escritura no S-31 transcrita por Lucas Álvarez 1986: 487-488.

22 El 2 de agosto de 1080, Rodrigo Vidal y otros otorgaron un pacto en favor del abad Fromarico de Samos para el cumplimiento de un contrato de arrendamiento efectuado en favor del primero en Santa María de Vila Adriani. Es la escritura no 159 del Tumbo de Samos transcrita por Lucas Álvarez 1986: 326.

23 Sobre el foro como sistema de cesión de tierras y como tipo documental en Galicia, se pueden consultar, entre otros, los siguientes trabajos: Villares 1982; García Oro 1987; Ríos Rodríguez 1993.
}

junto de datos, con el objetivo de no dejar lugar a la libre interpretación de las partes.

Los foros más antiguos que se conservan fueron redactados con menos formalidades y con escaso número de condiciones. Sin embargo, a medida que transcurrió el tiempo, el documento consolidó un esquema que se repetía y en el que se imponían como habituales ciertos datos y, sobre todo, numerosas cláusulas. La escritura comenzaba citando al propietario del bien que se iba a aforar, que en nuestro caso era siempre el monasterio. A continuación, se nombraba la persona receptora, seguida de una breve descripción de la propiedad o propiedades aforadas, indicando su nombre, su ubicación geográfica, los elementos que la formaban (casas, huertas, prados, árboles, heredades,...) y la posición de cada una respecto a las demás, el uso y producción de los bienes agrícolas, etc. Seguidamente se fijaba la duración del contrato, que en los foros estudiados era, predominantemente, de tres generaciones, coincidentes con las vidas de tres reyes de España. El resto del documento se ocupaba de establecer, con mayor o menor precisión, las demás condiciones que ambas partes habían de cumplir, entre las cuales eran una constante todas las siguientes:

1. Obligación del forero de labrar las propiedades y de mantener en buen estado las casas y demás infraestructuras, reparándolas en caso de ser necesario.

2. Obligación del forero de pagar una renta o canon al monasterio, ya fuese en especias o en metálico, indicando la fecha en la que esta debía ser entregada al monasterio cada año.

3. Prohibición para el forero de cesar en el pago de la renta establecida previamente, durante el periodo límite de dos años.

4. Prohibición para el forero de vender, trocar, cambiar, donar o enajenar las propiedades a persona alguna, sin conocimiento y aceptación previa por parte del monasterio.

5. Obligación del forero de pagar el coste de redacción de la escritura de foro, realizada siempre por un escribano público.

6. Cese del compromiso establecido en el caso de incumplimiento de la renta fijada o de alguna de las otras cláusulas.

7. Derecho del monasterio de recuperación de la propiedad al terminar la duración del contrato.

8. Derecho del aforado a ser defendido por el monasterio en caso de perturbación de sus propiedades, haciéndose este último también cargo de los costes que el proceso jurídico pudiese ocasionar.

Una vez expuestas las obligaciones y derechos de las partes, tenía lugar la aceptación de las mismas, seguida de la otorgación de la propiedad, especificando la fecha y el lugar de la celebración del acuerdo. En último lugar, se producía la firma de los otorgantes, receptores, testigos y escribano.

Las escrituras de foro son una fuente histórica fundamental en el campo de la investigación sobre el territorio por los datos que contienen sobre las características de las propiedades objeto de cesión. Pero, lo que realmente nos interesa resaltar ahora es que a través de la lectura de las más o menos numerosas cláusulas que contenían estas 
escrituras, podemos identificar la existencia de una serie de normas impuestas por los monjes como obligaciones para controlar la ordenación de su territorio. El carácter del documento, un contrato, y la relación de cláusulas que siempre contenía, eran la mejor garantía de que las personas que recibían las propiedades iban a cumplir todos los requisitos impuestos por los monjes pues, de otra forma, la cesión perdía su validez y las tierras y sus construcciones volvían a manos de la comunidad.

Sabedores de su condición de dueños del dominio directo de los bienes a ceder, además de fijar la obligación de los receptores de cuidar y mejorar las propiedades aforadas, una exigencia presente en toda escritura de foro, entre las cláusulas contenidas en estos documentos encontramos disposiciones que afectaban a las medidas que debían tener las nuevas construcciones, el lugar en el que tenían que estar ubicadas, el tiempo que se asignaba para su construcción, los materiales con los que se debían levantar, el uso al que estaban destinadas, etc. Algo similar ocurría con las propiedades agrícolas, cuyo destino, dimensión, estructura de cierre y otras muchas cuestiones estaban perfectamente fijadas.

A continuación vamos a ver algunos ejemplos del poder planificador ejercido por los monjes a través de las escrituras de foro realizadas para la cesión de propiedades que se ubicaban en la villa de Samos, el núcleo habitado que, con el paso del tiempo, se formó a los pies del monasterio. Su situación, inmediata al espacio sagrado de la clausura, obligó a los monjes a ejercer un mayor control en la organización de las construcciones y los espacios agrícolas vinculados a ellas, con el objetivo de no perjudicar el desarrollo de la vida monacal (Figura 5). Así lo demuestran diversos documentos.

Del 24 de abril de 1568 es una escritura de foro por la cual el monasterio cedía a un vecino de la villa, Pedro Corujo, y a su mujer, Isabel Vázquez, un terreno para hacer una casa, especificando tanto la ubicación exacta del lugar que se cedía como los materiales que debían emplear, quién debía costear la obra y el plazo para su ejecución, de la siguiente forma:

Sepan cuantos esta carta de foro vieren como nos fray Miguel de Zamora abad del monasterio de San Julián de Samos y por eso señor de toda su tierra y jurisdicción en lo espiritual y temporal que estando juntos en nuestro capítulo con los monjes del dicho convento llamados por son de campana tañida según lo habemos de uso y costumbre (...) que aforamos y damos en foro a vos Pedro Corujo sastre vecino de Samos que estáis presente y a Isabel Vázquez vuestra mujer ausente para vos y para ella y para otras dos personas después del postrimero de vos (...) un sitio para una casa de morada en este lugar de Samos junto a la casa donde al presente vive Benito Carballo cerrajero que allí la podáis hacer y hagáis para vuestra vivienda y de los dichos vuestros herederos y más con que la hagáis de paredes y de madera y losa a vuestra costa dentro de dos años (...)..$^{24}$

Del mismo año que la escritura anterior es otro documento expedido por el abad fray Miguel de Zamora para que el vecino, Cristóbal Vázquez, pudiese hacer una casa en la que habitar dentro de la villa. Al comienzo de la escritura,

24 1568, abril 24, Samos. «Foro del monasterio a Pedro Corujo de un sitio para una casa en Samos». Archivo Histórico Nacional (España) (en adelante, AHN). Foros y apeos de Ferreira y Samos que pasaron ante el escribano Andrés González [en línea]. Fondo Instituciones Eclesiásticas, Clero secular-regular. Libro 6492. Fol. 336r. Disponible en web: <http://pares.mcu.es/> el abad exponía que, con anterioridad, ya se cediera al citado vecino un lugar para hacer la construcción, pero que pronto la comunidad se diera cuenta de que la realización de una vivienda en la propiedad cedida afectaría a los terrenos de la clausura monacal, por su proximidad a la huerta del monasterio. A través de la nueva escritura cambiaban el lugar de ubicación de la vivienda, de la siguiente forma:

Nos fray Miguel de Zamora abad del monasterio de san Julián de Samos y por eso señor de toda su tierra y jurisdicción tanto en lo espiritual como en lo temporal decimos que por nos y junto con nuestro prior y monjes en nuestro capítulo aforamos e hicimos fuero a Cristóbal Vázquez y su mujer y otras dos personas del sitio para una casa a la carrera y camino que se abre del lugar de la Aira para este nuestro monasterio y después de eso nos pareció en el dicho nuestro convento que de hacerse allí la dicha casa era perjudicial del dicho nuestro monasterio y huerta de él y por ello dicho nuestro prior e algunos monjes del dicho nuestro monasterio fue modificado el sitio de la dicha casa del dicho Cristóbal Vázquez al camino que va para Bargado entre los caminos de abajo y de arriba y una huerta y aira por ende (...). ${ }^{25}$

\section{FIGURA 5}

La villa de Samos y su entorno natural, el valle del río Sarria definido por altas montañas

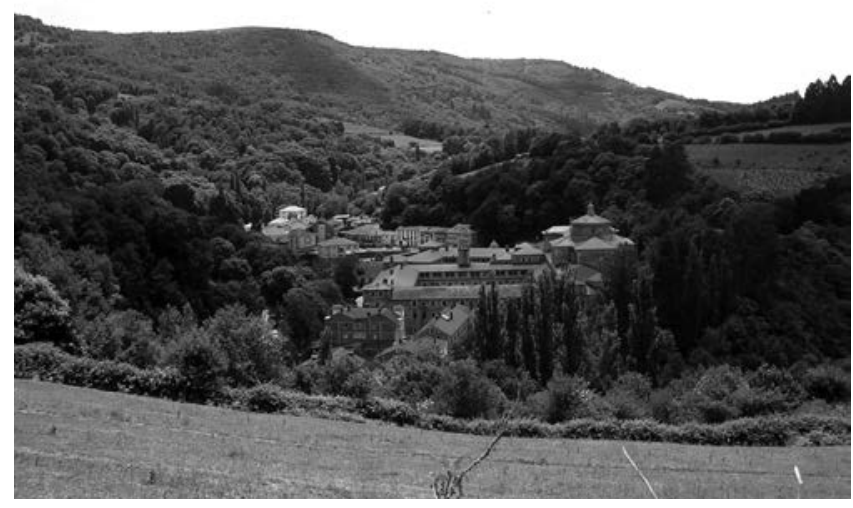

Fuente: Fotografía de la autora, 2012

FIGURA 6

Fotografía aérea de la villa de Samos y su entorno inmediato: los lugares y el antiguo cercado monacal

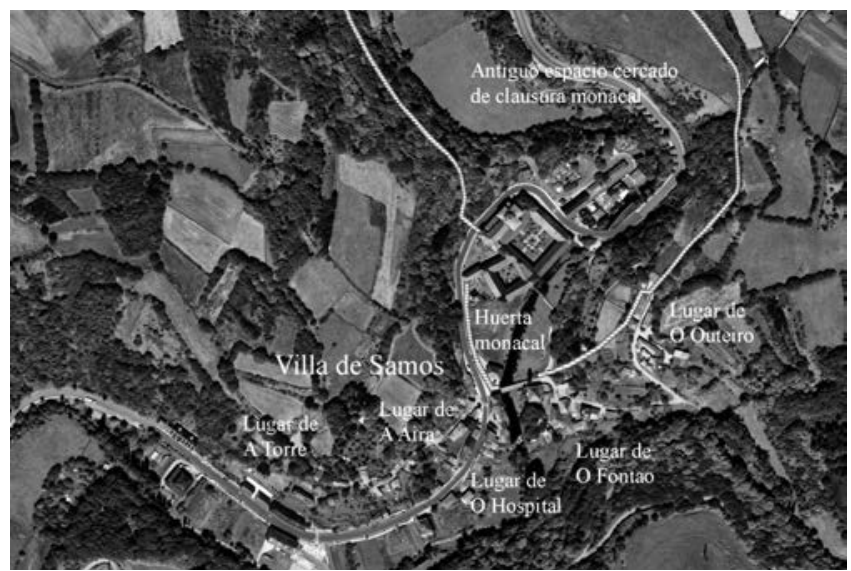

Fuente: Elaboración propia sobre Imagen Ortofoto. Plan Nacional de Ortofotografía Aérea de España (PNOA). Instituto Geográfico Nacional. 
Los dos fragmentos anteriores dejan ver, de forma muy clara, que los monjes determinaban, a su completa voluntad, el lugar en el que debían construirse las casas que, con el paso del tiempo, conformaron la villa de Samos y que, al fin del periodo establecido en los contratos de foro, volvían a su dominio directo. ${ }^{26}$ Para su elección tenían en cuenta que las nuevas construcciones no afectasen al espacio de la clausura monacal (Figura 6), hecho que podía ocurrir no sólo por la mayor o menor proximidad del terreno cedido, sino también por causa de la altura que alcanzaban las viviendas. Así se refleja en una de las cláusulas del nuevo foro realizado en 1578 a los vecinos Pedro Corujo e Isabel Vázquez. El documento contiene el contrato de cesión de una vivienda existente en el centro de la villa que los monjes cedían a los vecinos citados obligándoles a mantener y mejorar la construcción, pero prohibiéndoles que adquiriese mayor altura, por su situación muy próxima a la huerta monacal:

Sepan cuantos esta carta de fuero vieren como nos fray Gabriel de la Puebla abad del monasterio de San Julián de Samos (...) que aforamos y damos en fuero a vos Pedro Corujo sastre vecino del lugar de Samos para vos e Isabel López vuestra mujer (...) la casa que tenemos y es de este nuestro monasterio sita en la entrada del lugar de Samos en que solía vivir [Benito] Carballo cerrajero y vos al presente vivís con sus entradas y salidas usos y costumbres y con la plaza que está al lado de dicha casa hacia este nuestro monasterio $=$ a condición que en ningún tiempo podáis levantar la dicha casa más de lo que al presente está so pena que este fuero sea vaco y se os pueda deshacer sin que haya otro requerimiento $=y$ a condición que tengáis morada y reparada la dicha casa y nos paguéis de renta (...) una libra de cera (...) y a condición que fenecido este fuero y voces de la dicha casa con todos sus perfectos reparos y bienhechorías quede para nuestro monasterio sin por ello pagar cosa alguna (...). ${ }^{27}$

Asimismo, en la documentación conservada identificamos la preocupación de los monjes por el correcto dimensionado y diseño de las nuevas edificaciones y de la estructura de las tierras a ellas asociadas. En una escritura de foro de 1658, la comunidad religiosa otorgaba al escribano de la jurisdicción de Samos, Joseph de la Rivera, un sitio en la villa para hacer su propia casa y oficina. Entre las especificaciones del acuerdo figuraba la descripción tanto del lugar cedido, como de las dimensiones del terreno disponible para la nueva edificación:

Sepan cuantos esta carta de fuero vieren como nos el abad monjes y convento del monasterio de san Julián el real de Samos = estando juntos y congregados en nuestro capítulo a son de campana tañida según lo tenemos de uso y costumbre (...) que aforamos y damos en fuero a vos Joseph de la Rivera escribano de esta nuestra Jurisdicción el sitio nuestro que está pegado a la nuestra cárcel de esta villa de Samos que ha de ser desde la puerta principal que solía tener dicha cárcel hasta la esquina de abajo que no ha

26 Es lo que Rodríguez Ríos denomina derecho de retracto del bien aforado, una de las cláusulas que incluían los señores monásticos en los contratos de foro, con la finalidad de recuperar las propiedades y evitar que terceras personas pudiesen llegar a adquirirlas o incluso aislarlas, con la consecuente pérdida que esto suponía para el señorío eclesiástico. Ríos Rodríguez 1993: 228.

27 1578, octubre 21, Samos. Foro del monasterio a Pedro Corujo e Isabel Vázquez de una casa en el lugar de Samos. AHN. Samos. Foros años 1524-1833. Carpetilla 8. Fondo Instituciones Eclesiásticas, Clero secular-regular. Legajo 3452. Sin foliar. de ser más de tan solamente [once] pies de largo y [tanto] de ancho el cual dicho fuero os hacemos por vida de tres señores reyes de España que la primera ha de ser la vida del rey nuestro señor D. Felipe Cuarto que dios guarde y prospere felicísimos años y otras dos vidas después de los señores en estos dichos reinos de España consecutivamente en el cual dicho territorio podáis hacer un dicho escritorio a vuestra voluntad por el cual dicho territorio y escritorio nos habéis de dar y pagar durante las dichas tres personas reales medio Real en cada un año quede en diez y siete maravedíes los cuales nos habéis de encomenzar a pagar para el día de San Martín del año que viene de mil y seiscientos y cincuenta y nueve años (...) con condición que si estuvieredes tres años uno en pos de otro que no nos dieredes y pagaredes la dicha renta sea visto haber caído (...) en comiso y sea en nuestra elección y voluntad el tomaros el dicho territorio como lo que en él huvieredes perpetrado sin por ello nos pedir ni demandar cosa alguna (...). ${ }^{28}$

En otras ocasiones, las cláusulas recogidas en la escritura afectaban al uso que debían tener las construcciones. El ámbito en el que se sitúan las dependencias monacales estaba antiguamente delimitado y era de acceso restringido al pueblo laico. Sin embargo, el monasterio se ubicaba a escasos metros del trazado del camino de peregrinación hacia Santiago de Compostela, el Ilamado Camino Francés, que atraviesa el centro de la villa que se formó extramuros del monasterio. Al ser el asentamiento un lugar de tránsito, los monjes establecieron en él una construcción con la función de hospital que, durante los siglos de su dominio señorial, se cedió como vivienda a ciertos vecinos de la villa y, a su vez, estos adquirían el compromiso de atender y dar hospedaje tanto a los peregrinos que pasaban por el lugar como a pobres y huéspedes del monasterio.

La primera escritura de foro que se conserva sobre la llamada «casa del hospital» de Samos está fechada en 6 de marzo de 1560. A través de ella la comunidad cedía al vecino Alonso Broco y su mujer una vivienda en el lugar de la Aira y entre las cláusulas estipuladas figuraba la obligación de tener un cierto número de camas para atender a huéspedes del monasterio:

Sepan cuantos esta carta de fuero vieren como nos don Fray Benito de Gauna abad de nuestro monasterio de san Julián de Samos (...) que aforamos y damos en fuero a vos Alonso Broco vecino del lugar de Samos que estáis presente y a vuestra mujer ausente para vos y para ella y para otras dos personas después del postrero de vos (...) la casa nueva en que vos el dicho Alonso Broco vivís e moráis en el lugar da Aira extramuros de este nuestro monasterio con su aira según está y fue demarcada por los padres prior y mayordomo que es todo ello propio del dicho nuestro monasterio y vos lo aforamos a condición que seades sirvientes y obedientes a nos y a nuestros sucesores y a condición que favorezcáis nuestras huertas y tengáis la dicha casa levantada y en pie y morada por vos o por otro y la dicha aira cerrada y nos dedes y paguedes de renta canon y pensión en cada un año un buen carnero y tres gallinas (...) y a condición de que no pagando dos años arreo que perdáis el dicho fuero y sea baco y a condición de que tengáis

28 1658, octubre 11, Samos. «Foro por vida de tres señores reyes de España a favor de Joseph de Rivera, escribano, de un sitio pegado a la cárcel de Samos para hacer un escritorio en pensión de medio real cada un año, ante Benito Sánchez, escribano». AHN. Samos. Foros años 1524-1833. Carpetilla 8. Fondo Instituciones Eclesiásticas, Clero secular-regular. Legajo 3452. Sin foliar. 
dos camas de ropa en la dicha casa para recoger algunos huéspedes cuando vinieren hasta dicho nuestro monasterio y lugar de Samos (...). ${ }^{29}$

Son varios los documentos que se conservan con referencias a la «casa del hospital» a lo largo de los siglos XVI y XVII. Entre ellos, la última escritura de foro que hemos localizado está fechada en $1674 .{ }^{30}$ Fue redactada por el escribano Antonio de Pedrosa y forma parte de un libro de foros conservado en el Archivo Histórico Nacional. A través de ella el monasterio de Samos daba en foro a Marcial de Godoi, vecino de la villa de Samos y criado del monasterio, para él y su mujer y para otras dos generaciones más, la siguiente propiedad:

(...) una casa con su salido a la puerta trasera de ella con su parral que llaman el Hospital la cual es propia del dicho nuestro monasterio conviene aforar dicha casa en la renta y a la persona que delante irá declarada la cual dicha casa que así se aforamos demarca por la parte de hacia el río con cortiña y huerta que posee Antonio de Rubián y por la parte del salido de dicha casa donde está una parra demarca con era que poseen los herederos de Antonio Pérez la cual está cubierta toda ella de losa la cual dicha casa con todas sus entradas y salidas que le pertenezcan (...). ${ }^{31}$

Entre las cláusulas del contrato volvemos a encontrar la siguiente referencia:

(...) el cual dicho fuero de dicha casa y salido le hacemos con las condiciones y gravámenes siguientes que el dicho Marcial de Godoy y sus sucesores han de estar siempre obligados de dar posada a todos los pobres y peregrinos que vinieren por la dicha villa de Samos sin que en ello pongan reparo y en caso que no lo hagan el dicho Marcial de Godoy y sus sucesores, no tenga validación este fuero y caiga en comiso por cuanto le hacemos este dicho fuero en mucha menos renta de la que dicha casa merecía para que tenga cuidado él y sus herederos de dar siempre posada a los dichos pobres que pasaren y con condición que la dicha casa la han de tener siempre bien cubierta y reparada de todo lo necesario de manera que vaya en ascenso y no en disminución (...... ${ }^{32}$

Las escrituras de foro o arriendo también fueron utilizadas por la comunidad de monjes para mejorar el estado de conservación de las edificaciones que cedían, sin que ello supusiese un gasto para las arcas de la casa religiosa. Cuando ése era el principal objetivo de la cesión de una propiedad, entre las cláusulas del contrato figuraba la obligación del forero de reedificar las edificaciones lo que, en algunos casos, provocaba una paralela reducción de la renta a pagar por ellas durante el tiempo que duraban las obras de mejora o reconstrucción.

29 1560, marzo 6, Samos. "Foro de Alonso Broco de Samos». AHN. Foros y otros instrumentos [en línea]. Fondo Instituciones Eclesiásticas, Clero secular-regular. Libro 6526. Fol. 38v. Disponible en web: <http:// pares.mcu.es/>

Hay otra copia de esta escritura en AHN. Foros y apeos de Ferreira y Samos que pasaron ante el escribano Andrés González [en línea]. Fondo Instituciones Eclesiásticas, Clero secular-regular. Libro 6492. Fol. 124r. Disponible en web: <http://pares.mcu.es/>

30 1674, agosto 3, Samos. «Foro que el monasterio hizo a Marcial de Godoi de la casa de Samos llamada el Hospital con su salido». AHN. Foros otorgados ante Antonio de Pedrosa y otros escribanos [en línea]. Fondo Instituciones Eclesiásticas, Clero secular-regular. Libro 6525. Fols. 425r-426r. Disponible en web: <http://pares.mcu.es/>

31 Ídem.
Un ejemplo de este tipo de cláusulas lo encontramos en la escritura de arriendo otorgada por el monasterio a José López en $1777 .^{33} A$ través de este documento los monjes le arrendaban por el periodo de dieciocho años una casa situada en el lugar de Fontao de Abajo, llamada casa torre o casa de los médicos. Entre las cláusulas fijadas se incluía la obligación del receptor del arriendo de componer y reedificar la vivienda cedida que, una vez finalizase el contrato, volvería a manos de la comunidad con todas las mejoras hechas sobre ella.

Dentro del Real Monasterio de San Julián de Samos a primero día del mes de Marzo año de mil setecientos setenta y siete ante mí escribano y testigos estando presentes su Reverendísima el Padre Maestro Fray Íñigo Rabuñade Abad y Señor de este Real Monasterio su Jurisdicción y Abadía en lo espiritual y temporal, sus padres (...) todos monjes profesos, y conventuales en este dicho real Monasterio juntos a son de campana tañida como lo tienen de uso y costumbre; y confiesan ser la maior parte hacen por sí, y en nombre de los demás ausentes, enfermos, impedidos por quienes prestan caución de ratio en forma, y dijeron que este real Monasterio tiene por suya propia una casa con su alto y bajo fayado y paredes al sitio que llaman del Fontao en esta Villa de Samos y en que hasta ahora por Arriendo habitaba Francisco Montero y su mujer que confina con la aira de Fontao y con casa de Manuel López [...] y por Joseph López vecino de dicha Villa se enteró pidiendo su [Reverendísima] y [...] comunidad se le hiciese arriendo de ella que a su costa la reedificaría de los perfectos que necesitaba y daría lo que fuese justo por ella de renta anual, tratose con los Padres de consejo y lo tuvieron por bien, y en su conformidad desde luego y por el tiempo y espacio de nueve años, y después por otros nueve más arriendan y dan en arrendamiento a dicho Joseph López para él y quien represente su derecho la referida casa de Fontao que antes tenía el nombre de casa de los Médicos según es bien conocida con las condiciones siguientes = La primera que la ha de componer y reedificar como lo ofreció ponerle y mantenerle vividera de manera que vaya en aumento y no venga en disminución reedificando sus paredes piso tejado y maderas; que por razón de ella ha de dar y pagar en cada uno de los nueve años y otros nueve más catorce reales de Vellón principiando la primera paga para el mes de Marzo del año que viene de mil setecientos setenta y ocho y las demás sucesivas al mismo plazo puestos en la mayordomía de este Monasterio sin descuento alguno en cuya renta y cantidad se le arrienda por cargarse de su reedificación; que fenecidos dichos diez y ocho años nos la ha de dejar libre y desocupada a este Monasterio sin pedir ni descontar cosa alguna pero si el Monasterio no la necesitare para poner en ella persona que sea precisa para servicio de la Santa Comunidad, en tal caso será dicho Joseph López o persona que represente su derecho referido en segundo arriendo al tanto que otro por ella de y prometa (...) a todo lo referido el Joseph López que aceptó esta escritura de arriendo a su favor otorgada (...)..$^{34}$

En otros casos, las cláusulas no sólo incluían la obligación de la reedificación, sino también el modo preciso de llevar ésa a cabo. Un buen ejemplo de ello es la escritura de foro

33 1777, marzo 1, Samos. "Arriendo hecho a favor de José López de una casa Torre, y Casa de los Médicos, por tiempo de 9 años y 9 más, en renta anual de 14 reales, año de 1777, escribano Francisco Benito de Losada». AHN. Samos. Arriendos 1670-1839. Carpetilla 3. Fondo Instituciones Eclesiásticas, Clero secular-regular. Legajo 3452. Sin foliar.

34 Ídem. 
redactada en 1832 para aforar, de nuevo, la casa torre del Fontao de Abajo al vecino José López, así como un conjunto de terrenos y edificaciones auxiliares a ella asociadas. ${ }^{35} \mathrm{El}$ mal estado de conservación de la vivienda y la incapacidad de la comunidad para costear su reforma derivaron en la decisión de cederla para siempre en foro, a cambio de una renta anual estipulada y de una serie de cláusulas muy concretas, tal y como podemos ver en el siguiente fragmento del documento:

(...) como dueños de una casa y más que se expresa sita en términos de esta villa han visto muy de cerca los gastos que les propiciaba su estado deplorable para reedificarla, y a evitarlo han deliberado reunirse los P. P. del consejo para tratar lo concerniente al bienestar de este Monasterio según lo tienen de costumbre, lo cual tuvo efecto en consejo pleno del día veintiséis de abril último, y de que recibió por acta del mismo día que habiéndose presentado estados para tomarla en fuero con obligación de reedificarla, conociendo la utilidad que resulta al Monasterio de asegurar una renta perpetua en aquel edificio sin exponerse a más desembolso, y que la ofrecía en este caso es más que la que rentaba por arriendo, han resuelto el otorgamiento de dicho fuero (...) Por consecuencia usando de estas facultades y derecho que les asiste, desde luego por virtud de la presente y en la forma que más cabida tenga, por sí y sucesores, aforan y dan en fuero para siempre a José López vecino de esta misma villa, que se halla presente y recibe para sí y los suyos a saber: una casa que se nombra da Torre y antiguamente de los Médicos sita en el lugar de Fontao a la otra parte del Puente con su terreno que la fronteriza por la parte del norte, y se halla a inculto, $y$ en que susiste otra caseta terrena fabricada por el recipiente, cuyo terreno en que se incluye la plazuela correspondiente y propia de ambas casas, se entiende desde la primera esquina de la casa principal que dice al poniente según la [entrada] que está y paredón de la escalera de manera estean en rectitud frente al norte hasta llegar al camino que sale del Puente y va al lugar de Outeiro, Villa de Tres y otras partes, dentro de la cual y terreno de plazuela que va incluso hubo antiguamente otra caseta de los padres otorgantes que sirvió de horno y pertenecía a la de este fuero; la cual se compone aunque deteriorada, de dos cuartos altos, dos cuadras y cocina terrena con su horno cubierta de losa y madera, socorrida con la era y servicio de una puerta al norte, otra para las cuadras al poniente otras al medio día, y tres ventanas por la misma parte del poniente, hacia cuyo sitio también tiene puertas terrena la otra caseta, según todo ello incorporado demarca por la parte de abajo que es al mediodía y parte del poniente con casas del foral del Fontao de abajo que poseen Domingo Rodríguez, Manuel García, Juan López, Agustín de Castro y Ramón Ramil, Callejón en medio, al poniente con el camino que sale del Puente, y gira por delante la casa de Juan López al Rigueiro do Fontao y otras partes plazuela que da entrada a la casa y terreno de este fuero, así como a las demás en medio, por el norte con dicho camino que va al lugar de Outeiro y Villa de Tres, y al naciente con la era de Majar perteneciente a los dos forales de Fontao de arriba y Fontao de abajo (....). ${ }^{36}$

35 1832, agosto 26, Samos. «Foro de la casa nombrada da Torre en Samos otorgado por el Monasterio en 26 de Agosto de 1832 a favor de José López, en renta de 16 reales primera paga 25 de Julio de 1835 Escribano Miguel Somoza de Tuimil». AHN. Samos. Foros años 1524 1833. Carpetilla 8. Fondo Instituciones Eclesiásticas, Clero secularregular. Legajo 3452 . Sin foliar.

36 ídem.
Una vez descritos y deslindados los bienes objeto de foro, se especificaban las condiciones del mismo, de la siguiente forma:

Todo lo cual (...) le aforan por suyo propio con todas sus entradas y salidas, usos, costumbres, derechos y servidumbres que tiene y le corresponden bajo las condiciones siguientes: que el recipiente y herederos ha de fabricar de nuevo la casa aforada, ya sea en el mismo terreno que ocupa la principal o ya en el que la fachea por la parte del norte y existe la otra caseta, dándole las entradas y salidas con luces suficientes que le corresponden, con tal que por la parte de entre mediodía y poniente frente al callejón y casas del foral del Fontao de abajo, que rodean la de que se trata, no presente más puertas y ventanas, de las que en la actualidad tiene que fabricada que sea dichas casa y huerta a que quiera reducir parte de lo aforado, la ha de tener siempre bien cuidada cultivada reparada y perfectada de todo lo necesario, de manera que aumente y no disminuya: que no lo ha de poder vender, trocar pensionar, partir ni en manera alguna disponer de ella en perjuicio de este instrumento y renta que irá declarada y que por todo ello ha de pagar anualmente de renta a los padres otorgantes y quien les suceda diez y seis reales vellón en dinero y no en otra cosa, puestos y pagos por su cuenta y riesgo, y día veinte y cinco de Julio de cada año en la Mayordomía de este Monasterio principiando a verificarse la primera paga para el que viene del año entrante de mil ochocientos treinta y tres, y sucesivamente por el mismo sin atraso ni descuento bajo apremio y costas, añadiendo por esencial y expresa condición de que el recipiente caso de construirse el nuevo edificio en el terreno que fachea la casa principal, ha de ser visto demoler esta inmediatamente, de suerte que no resulten dos casas, ni en ningún tiempo más que un solo vividor. Con lo cual cumpliendo con dichas condiciones y no sin ellas los padres otorgantes desde ahora para siempre se apartan y a sus sucesores de todo el derecho y acción que tenían a lo que llevan aforado, y lo transfieren en el recipiente y los suyos, (....). ${ }^{37}$

El control ejercido por los monjes en la ordenación del territorio de su coto, de acuerdo con sus intereses, no sólo se limitó al ámbito de la villa, sino que se extendió por todos los dominios de su jurisdicción. De ello es buen ejemplo la escritura de foro expedida por el monasterio en 1577, por la cual otorgaban a Inés Ares de Armesto y su hijo Pedro Díaz de Freijo, habitantes de la villa, los lugares de Reboredo, Coiñas y Bargado, en posiciones más alejadas del monasterio. ${ }^{38}$ Entre las cláusulas de la escritura encontramos referencias a la prohibición de construcción de viviendas en alguno de esos lugares, a la imposibilidad de aumentar los límites de las propiedades agrícolas aforadas, al número máximo de árboles que podían estar plantados en ellas, a la obligación de mantenerlas cerradas con muros e, incluso, al tipo de cultivo al que debían estar destinadas.

Sepan cuantos esta carta de fuero vieren como nos fray Gabriel de la Puebla abad del monasterio de San Julián de Samos (...) abad, monjes y convento del dicho nuestro monasterio estando juntos y congregados en la iglesia del dicho monasterio llamados y convocados por nos el dicho abad otorgamos y conocemos por el tenor de la presente

37 Ídem.

38 1577, marzo 16, Samos. "Foro hecho a Pedro Díaz del lugar de Reboredo, Coíñas y Bargado. Pasó ante Francisco López Somoza». AHN. Samos. Foros años 1524-1833. Carpetilla 8. Fondo Instituciones Eclesiásticas, Clero secular-regular. Legajo 3452. Sin foliar. 
carta que aforamos y damos en fuero a vos Inés Ares de Armesto mujer que la presente sois de Alonso de Rebolle y mujer primera que habéis sido de Alonso Gallina escribano y para Pedro Díaz de Freijo vuestro hijo y del dicho Alonso Gallina (...) la cortiña y agro del lugar de Reboredo que está en bajo de las casas de dicho lugar hacia el río según al presente está sobre sí cerrado y anda en agro juntamente con el prado que dentro del está en bajo del dicho agro sin que se pueda más acrecentar ni alargar más de lo que al presente está y más los árboles del dicho lugar frutales y más el agro y heredad de Coiñas según está cerrado sobre sí (...) y más el agro de Bargado eso mismo según está cerrado y vos la dicha Inés Ares hasta ahora lo traéis a labradío por nos y en nuestro nombre con sus entradas y salidas a condición que vos y el dicho vuestro hijo y voces y personas tengáis las dichas heredades labradas y reparadas y puestas en buen paramiento otro sí a condición que vos los susodichos y las dichas vuestras voces ahora ni en tiempo alguno no podáis ni puedan morar en el dicho lugar de Reboredo ni otra persona alguna ni tener en él casa ni habitación de ninguna manera ni en él podáis tener otra labranza ni granjería alguna más de solamente el dicho agro según de su uso está limitado el que se ha de labrar de fuera del dicho lugar y habiendo lo contrario por el mismo caso sin otra sentencia ni determinación este fuero sea vaco y perecido y caiga en comiso y demás de ello podamos libremente sin por ello hacer fuerza ni delito por vuestra propia avaridad derribar y asolar las dichas casas y habitaciones y quitaros otra mayor labranza de más de dicho agro otro sí a condición que el dicho agro lo habéis de labrar y cerrar de pared y de otra cierra que no sea leve en que se pueda saltar la leña, palos y ramas de nuestros montes so la pena de comiso = y otro sí a condición que la cortiña y heredad que se dice da Seara que hasta ahora habéis labrado la habéis de dejar a monte y en plano sin la arar ni abarbechar jamás en tiempo alguno como el dicho lugar de Reboredo y con las mismas condiciones de manera que todo el dicho lugar de Reboredo y lo a él perteneciente juntamente con la dicha cortiña da Seara ande y esté siempre en monte excepto el dicho agro, prado y heredad arriba dicho (...). ${ }^{39}$

Treinta y tres años después de ser otorgada la escritura anterior, un nuevo documento fue redactado en 1610, como consecuencia de algunos problemas que, con el paso del tiempo, habían surgido en la forma de habitar el lugar de Reboredo. ${ }^{40}$ Se trata de una escritura de concordia realizada entre el monasterio de Samos y Pedro Díaz de Freijo. En ella la comunidad de Samos informaba de que el referido forero había construido una vivienda nueva en el lugar de Reboredo. Asimismo, había realizado nuevas plantaciones en las propiedades agrícolas y había levantado nuevos cierres, siguiendo los mandatos de los monjes:

En el monasterio de San Julián de Samos a dos días del mes de [Febrero] de mil y seiscientos y diez años ante mí escribano y testigos parecieron presentes de la una parte su paternidad el maestro fray Baltasar Guerrero juntamente con su convento (...) y de la otra Pedro Díaz escribano y vecino del lugar de Lastres del Rial y dijeron que por cuanto el dicho Pedro Díaz tenía en fuero de este monasterio el lugar de Reboredo que se había hecho Alonso Gallina su padre difunto y que del había dos voces y estando vivo

\footnotetext{
39 Ídem.

40 1610, [febrero] 2, Samos. «Escritura del monasterio y Pedro Díaz escribano. Concordia». AHN: Samos. Foros años 1524-1833. Carpetilla 8. Fondo Instituciones Eclesiásticas, Clero secular-regular. Legajo 3452. Sin foliar.
}

el dicho fuero y voces Inés Ares de Armesto su madre había ganado otro nuevo fuero del dicho monasterio de la heredad y prado que estaba debajo de las casas de dicho lugary árboles frutales del y del agro y prado de Coiñas y heredad de Bargado en renta y pensión de cuatro anegas de pan y una libra de cera de renta según el fuero había pagado ante Francisco López escribano a que se referían y después de esto el dicho Pedro Díaz había puesto pleito al dicho monasterio y la dicha su madre diciendo que tenía fuero del dicho lugar en renta de cuatro anegas de pan y que se le debía de cumplir y alcanzar escritura en su favor y en virtud de ella el dicho monasterio y su convento habían hecho escritura de confirmación del dicho fuero (...) en favor del dicho Pedro Díaz y en virtud de ella podía haber siete o ocho años poco más o menos que el dicho Pedro Díaz había hecho y edificado de nuevo en el dicho lugar una casa con su sobrado buena y hecho cierres y plantados en el dicho lugar (...). ${ }^{41}$

Sin embargo, la comunidad religiosa consideraba que una vivienda en el lugar de Reboredo iba en contra de sus propios intereses, pues se encontraba muy cerca de los montes del monasterio. Por esa razón, a través de esta escritura de concordia, el monasterio de Samos recuperaba el dominio directo sobre el lugar de Reboredo que llevaba Pedro Díaz y, a cambio, este vasallo obtenía en foro el lugar de Pereiro, en Vilamelle, a donde se le permitía trasladar la piedra que usara en la construcción de la vivienda para levantar nuevos muros de cierre de las propiedades de ese lugar:

(...) ahora su paternidad juntamente con su convento dijeron que atento el dicho lugar estaba junto pegado con los montes de este dicho monasterio y que hacía mucho daño y perjuicio a este monasterio y le era muy necesario los montes del y por evitar semejante daño y el provecho que venía a este monasterio eran concertados con el dicho Pedro Díaz (...) y traspasaba en el dicho monasterio y su convento el derecho que tenía y los montes y habitación del dicho lugar quedando en su fuerza y vigor el dicho fuero que a la dicha Inés Ares de Armesto por sí y el dicho Pedro Díaz su hijo había alcanzado del dicho monasterio con que el dicho Pedro Díaz pueda llevar losa y madera de la dicha casa y la piedra de ella cierre la dicha heredad y todo lo demás fuera del dicho fuero quede al dicho monasterio y esto por razón que hoy dicho día su paternidad y convento en recompensa de dicho lugar y montes de él hicieron fuero al dicho Pedro Díaz del lugar do Pereiro de Vilamelle en renta de siete anegas de pan de las ocho en que antes andaba (...) y que atento que por el dicho fuese que la dicha Inés Ares de Armesto había alcanzado del dicho monasterio por razón de la heredad prado y árboles del dicho lugar do Reboredo había de pagar dos anegas de pan y una libra de cera = y por el agro y prado de Coíñas y heredad de Bargado dos anegas de pan = y se entiende haya de pagar las dichas dos anegas de pan y una libra de cera desde que se quitare la dicha habitación del dicho lugar como va dicho y desde allí en adelante se confirma y aprueba el dicho fuero (...). ${ }^{42}$

La escritura de concordia anterior muestra, de una forma muy clara, como los monjes tenían la capacidad de deshacer los acuerdos de cesión de propiedades cuando cualquier nuevo factor, surgido en el paso del tiempo, afectaba a los intereses de la comunidad.

\footnotetext{
41 Ídem

42 Ídem.
} 


\section{A MODO DE CONCLUSIÓN}

De todo lo expuesto podemos concluir que el tipo documental analizado y los ejemplos dados demuestran, mejor que cualquier otro instrumento, que los monjes ejercieron un verdadero control sobre la ordenación del territorio de su coto jurisdiccional. En el papel de señor dentro de los límites de su jurisdicción, el abad se preocupó porque la disposición y características de las nuevas construcciones no afectasen al desarrollo adecuado de la vida en comunidad, principalmente en el ámbito inmediato a la casa monacal, así como porque los elementos de cada lugar aforado fuesen correctamente explotados, mantenidos y mejorados por las personas a las que se los cedía y transformados según las condiciones establecidas por los monjes.

Para alcanzar ese objetivo no se creó un documento de planeamiento concreto, sino que la comunidad utilizó un instrumento relacionado con la explotación de la tierra y de las construcciones existentes en ella. El foro fue un documento perfecto para ejercer el control sobre la ordenación del territorio habitado, porque sus cláusulas relacionaban las condiciones, más o menos estrictas, con las que se podía habitar, proteger y transformar el medio existente. En otras palabras, las cláusulas de las escrituras de foro eran disposiciones establecidas por la comunidad monacal en las que, con un sentido planificador, quedaban fijadas las posibilidades de alturas, usos, ubicación, dimensiones, alineaciones,..., tanto de las construcciones, como de las propiedades agrícolas, controlando así el proceso de transformación del medio, protegiendo las áreas territoriales de administración directa por parte de la comunidad y, en definitiva, definiendo la imagen del paisaje urbano y rural dentro del coto jurisdiccional.

\section{FUENTES DE ARCHIVO}

España, Archivo Histórico Nacional, Madrid (AHN):

Foros y apeos de Ferreira y Samos que pasaron ante el escribano Andrés González [en línea]. Fondo Instituciones Eclesiásticas, Clero secular-regular. Libro 6492. Disponible en web: <http://pares.mcu. es/>

Samos. Foros años 1524-1833. Carpetilla 8. Fondo Instituciones Eclesiásticas, Clero secular-regular. Legajo 3452.

Foros y otros instrumentos [en línea]. Fondo Instituciones Eclesiásticas, Clero secular-regular. Libro 6526. Disponible en web: <http:// pares.mcu.es/>

Foros otorgados ante Antonio de Pedrosa y otros escribanos [en línea] Fondo Instituciones Eclesiásticas, Clero secular-regular. Libro 6525. Disponible en web: <http://pares.mcu.es/>

Samos. Arriendos 1670-1839. Carpetilla 3. Fondo Instituciones Eclesiásticas, Clero secular-regular. Legajo 3452.

\section{BiBLIOgRAFÍA}

Andrade Cernadas, J. M. 1997. El monacato benedictino y la sociedad de la Galicia Medieval (siglos X al XIII). A Coruña: Publicacións do Seminario de Estudos Galegos/Edicións do Castro.

Arias Arias, P. 1950. Historia del Real Monasterio de Samos. Santiago de Compostela: Imprenta, Lib. y Enc. Seminario Conciliar.

Arias Cuenllas, M. 1981. "El monasterio de Samos desde sus orígenes hasta el siglo XI». Archivos Leoneses 70: 267-350.

Arias Cuenllas, M. 1983. "El monasterio de Samos durante los siglos XI y XII». Archivos Leoneses 73: 7-82.

Arias Cuenllas, M. 1992. Historia del monasterio de San Julián de Samos. Samos: Monasterio de Samos/Diputación Provincial de Lugo.

Duro Peña, E. 1977. El Monasterio de San Esteban de Ribas de Sil. Ourense: Instituto de Estudios Orensanos «Padre Feijoo» de la Diputación Provincial.

García Oro, J. 1987. Galicia en los siglos XIV y XV. Tomo I. A Coruña: Instituto «P. Sarmiento» de Estudios Gallegos/Fundación Pedro Barrié de la Maza Conde de Fenosa.

López Alsina, F. 1993. «Millas in giro ecclesiae: el ejemplo del monasterio de San Julián de Samos». Estudos medievais 10: 159-187.

López Alsina, F. 1995. "Valor simbólico del espacio urbano medieval», en Santiago de Compostela: la ciudad como presente: 82-89. Santiago de Compostela: Consorcio de Santiago.

López Alsina, F. 2013. La ciudad de Santiago de Compostela en la Alta Edad Media. Santiago de Compostela: Consorcio de Santiago/ Universidad de Santiago de Compostela.

López Quiroga, J. y Rodríguez Lovelle, M. 1999-2000. «Un modelo de evolución del poblamiento rural en la Galicia interior (s. v-x): el territorio entorno a la depresión de Sarria y el monasterio de Samos». Boletín del Museo Provincial de Lugo 9: 173-185.

Lucas Álvarez, M. 1986. El tumbo de San Julián de Samos (siglos VIIIxII). Estudio introductorio. Edición diplomática. Apéndices e índices. Santiago de Compostela: Obra Social Caixa Galicia.

Lucas Álvarez, M. y Lucas Domínguez, Pedro. 1996. El Priorato benedictino de San Vicenzo de Pombeiro y su colección diplomática en la Edad Media. Sada-A Coruña: Seminario de Estudos Galegos/ Edicións do Castro.

Pallares Méndez, M.a C. 1978. «Los Cotos como marco de los Derechos Feudales en Galicia durante la Edad Media (1100-1500)». Liceo franciscano 91-92-93: 201-225.

Ríos Rodríguez, M. a L. 1991. Relaciones contractuales agrarias en la Galicia medieval: los orígenes del foro (1150-1350). Tesis doctoral. Universidad de Santiago de Compostela.

Ríos Rodríguez, M.a L. 1993. As orixes do foro na Galicia medieval. Santiago de Compostela: Universidad de Santiago de Compostela.

Rodríguez Cancio, M. R. 1978. Formación, consolidación y evolución del dominio del Monasterio de San Julián de Samos en los siglos IX al XIV (850 a 1325). Tesis de licenciatura inédita. Universidad de Santiago de Compostela

Rodríguez González, M. a C. 2008. «San Xulián de Samos. Unha instancia de poder na Idade Media», en San Xulián de Samos: Historia e arte nun mosteiro, Opus Monasticorum III: 49-72. Santiago de Compostela: Xunta de Galicia.

Vázquez González, M. 1991. «El dominio del Monasterio de San Julián de Samos en el siglo XIV (1325-1380)». Cuadernos de Estudios Gallegos 34, 104: 95-112.

Villares, R. 1982. La propiedad de la tierra en Galicia 1500-1936. Madrid: Siglo XXI de España editores. 